\title{
GEOGRAPHY AND THE IRREGULAR MODERN FORTRESS CITY (GIRONA 18TH AND 19TH CENTURIES)
}

\author{
Ramon RIPOLL ${ }^{1}$, Jordi GOMIS ${ }^{2}$ (i), Carlos TURÓN ${ }^{3}$ iD, Miquel-Àngel CHAMORRO ${ }^{4}$
}

DOI: 10.21163/GT_2020.152.05

\begin{abstract}
:
The regular modern fortress city of the seventeenth and eighteenth centuries has been widely studied. However, the irregular modern fortress city, which adapts to the rugged geography of the site, has, to date, been scarcely analysed. In the case of the latter, the irregularities of the terrain force moulding, changing and introducing major changes to common, regular, symmetrical defences. In these cases, geography and construction complement each other unusually, enriching the freer, more functional layout of the bastions, curtain walls and complementary structures. The aim of these changes is both financial and defensive at the same time. The peculiar geography of the traditional city of Girona -Catalonia- is a magnificent example of an irregular defensive approach in modern European history.
\end{abstract}

Key-words: Geography, Topography, Fortress City, Urban Geography, Civil Engineering

\section{INTRODUCTION}

Analysis of the strategic, geographic and formal uniqueness of the fortress city of Girona in Catalonia demonstrates the adaptation of the rigid, geometric defensive structures of the period to the singularities of the irregular, rugged terrain (Galindo, 1996). The work methodology used is based on the study of the formal and topographic characteristics of the defences of the city of Girona and the high degree of compatibility between them. This research requires reviewing and verifying the extent to which the scientific determinism of the modern era promoted by the science of defence of military engineers, of whom Sebastian le Preste de Vauban is one of the greatest exponents, adapted to the indeterminacy of common sense promoted by traditional customs and master builders. The findings show that defensive functionality (regular typology) was not only compatible with irregular topography, but benefited from these irregularities (morphology of the site).

The analysis highlights how the mathematical principles proposed by Vauban (La Preste de Vauban, 2010) were relaxed to extremes of adaptation to a complex environment in historical, urban, geographical, fluvial etc. terms. In this case the historical data are compared with studies of drawings and diagrams that illustrate this approach. The documentary sources used are the Municipal Archives of Girona, the Girona Historical Archive and the Archive of the Crown of Aragon (AHM, AHG, ACA).

\footnotetext{
${ }^{1,4}$ Universitat de Girona, 61 Maria Aurèlia Capmany Street, 17003-Girona, Spain, ramon.ripoll@udg.edu, mangel.chamorro@udg.edu

${ }^{2,3}$ Universitat Rovira i Virgili, 26 Països Catalans Avenue, 43007-Tarragona, Spain, jordi.gomis@urv.cat, carlos.turon@urv.cat
} 
It should be recalled that modern fortress cities became widespread in the seventeenth century following the defence theory of military engineers in order to counter the great advances in military attack and siege tactics (Hughes, 1850). Thus, the new modern artillery, characterized by its huge destructive capacity, had to be counteracted with the construction and strengthening of fortresses and cities. Improved war machines forced improving the machines of defence. The machinery was subject to the principles of Vauban, who related the new schemes of attack with new schemes of fortification while military theory scientifically related form, space, time and means. The goal, in both cases, was to reduce the time and the means of any siege or defence, based on better controlling the form or the space.

It is clear that this eminently theoretical approach has its limits and so it is partially true. In this sense, it is widely known that no fortress could achieve unlimited defence; the fortress was therefore a means that, in the worst situation, allowed delaying surrender. These theories were applied to both newly built fortifications and to renovations of old military constructions (Ripoll, 2010). In this case, medieval cities adapted to new defensive strategies: the placing of bastions separated by a perfectly calculated distance, the construction of concentric defensive lines, and the arrangement of curtain walls, moats, palisades, underpasses, and complementary elements. Specific basic principles in the form, but also open to interpretation, that allowed for dual adaptation to the principles of the military treatises of the time and to the geography of the site. In this case it is demonstrated that the scientific, mathematical and military training of military engineers was not a closed, repetitive method but one that enabled creating open defensive typologies according to the topographical and historical circumstances of the site.

In this sense, the small city of Girona, with just 8,000 inhabitants was, militarily speaking, an important city in modern times because of its location on the central communication route in southern Europe between Spain and France (Ripoll, 2001). And it is precisely its strategic situation that forced it in the seventeenth century to adapt to the new military construction systems. Girona's functionality as a fortress city is amply demonstrated by the eight attacks suffered by the city, in the eighteenth century and the first half of the nineteenth century.

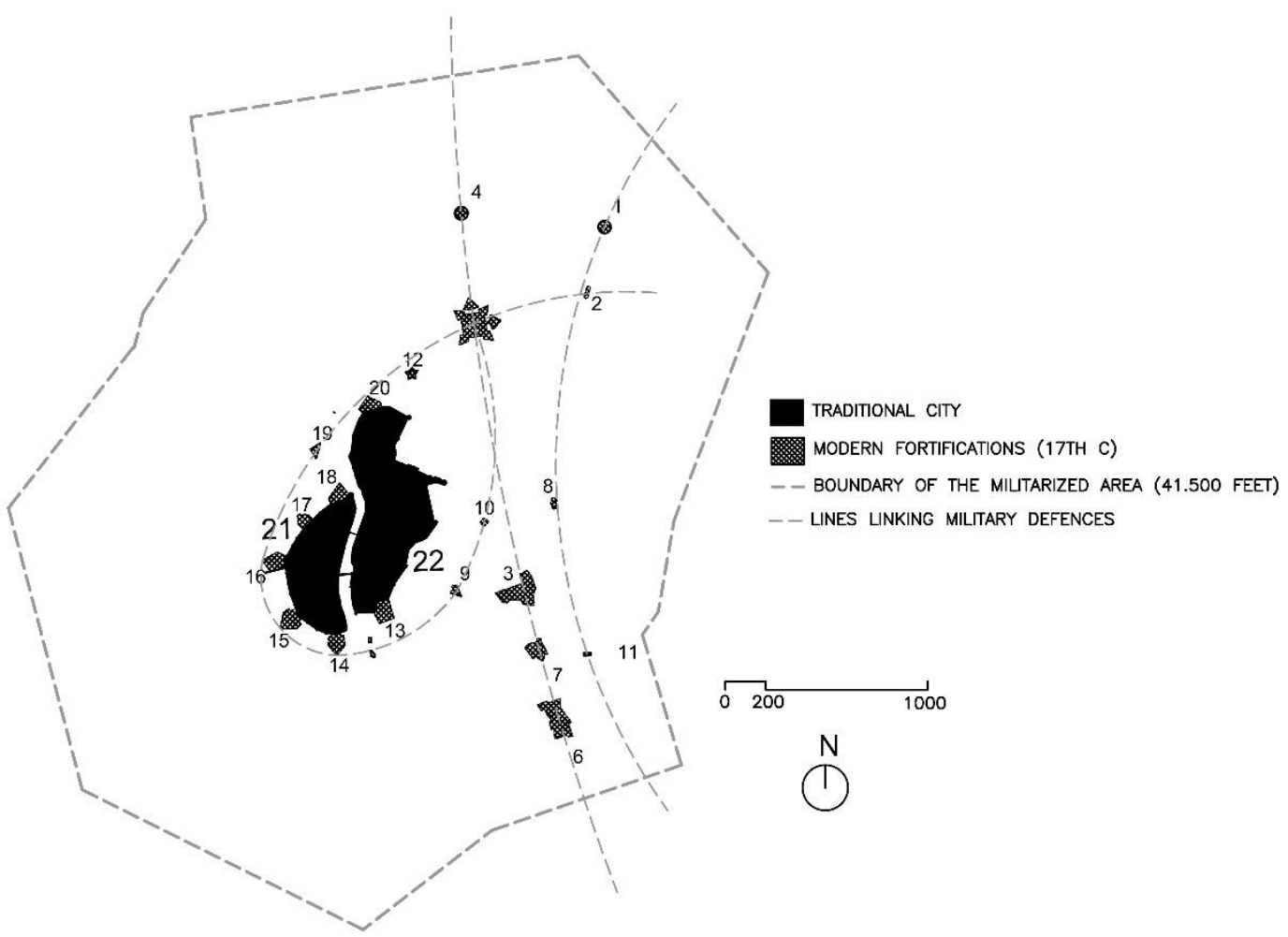

Fig. 1. Diagram of the fortifications of the city of Girona in the 18th and 19th centuries

(Drawing by R. Ripoll, private archive, 2018) 
These sieges occurred in: 1710 (41 days of war), 1712 (377 days), 1808 (2 days), 1808 (32 days), 1809 (222 days), 1821 (2 days), 1827 (31 days) and 1843 (39 days). In three of them (1711, 1809 and 1843 ) the city was conquered, while in the rest, the city resisted the attackers. The city of Girona was thus under siege for 746 days over a 150 -year period. This accounting does not take into account the pre-war periods when the citizens were forced to work directly preparing defensive constructions and indirectly to pay for these renovations.

Situations are also known in which citizens were required to ready the defences of the city without any fighting taking place. This is the case of the Great War (1793-1795) in which the city of Girona, after carrying out highly costly building repairs, did not join the conflict (Various authors, 2006).

The most difficult times lived by the city of Girona are the sieges of the Napoleonic Wars (18081814). Undoubtedly, it was the time when the theoretical approaches of the military ratio between form, space, time and means, discussed above, were tested with excellent results in military terms and exceedingly negative results in social terms (Ripoll, 2005). In this case, the well-arranged city defences allowed resistance that exceeded any conceivable expectation, at the cost, however, of subjecting the population to extreme, inexplicable nutritional, health and psychological situations. The defensive constructions worked better than expected, resisting a siege from 5 May to 10 December 1809 (Fig. 1), the population being halved and the civil destruction of homes and urban facilities generalized. Two hundred and thirty-three buildings were demolished, pavements of streets and squares destroyed, and there were a large number of wounded, sick and dead (Various authors, 2008). The human situation worsened with the spread of epidemics due to air and water pollution during the last weeks of the war, according to the descriptions by the French after the occupation of the city (Ripoll, 2009).

\section{NATURAL DEFENCES}

The transformation of the precarious traditional urban defences, of medieval origin, to the new layout of irregular fortified city with bastions presided over by a regular, independent main fortress, was repeated in most fortified cities in southern Europe throughout the seventeenth century. This approach was executed adapting each city to modern defensive layouts and the topographical characteristics of the site. The case of the city of Girona, and its unique geographical location is of great interest to any scholar of modern defensive strategy. Firstly, we can distinguish two different areas. The upper, rugged part to the east of the city consists of rocky terrain and is characterized by its great defensive vulnerability. In contrast, the part to the west of the city consists of crop land and is characterized by its susceptibility to flooding in times of heavy rain (Various authors, 1992). Due to the limitation of urban space, the mitigation system was also designed as the recreation area (Nusit et al. 2019) named La Devesa.

The special geographical factors that play an important role in the defence of the city are, first, the periodic flooding of the Girona plain, and secondly the especially rocky subsoil of the mountainous area. The flood-experienced people are likely to implement the mitigation measures, to avoid or reduce the damages associated with floods (Odidi et al, 2020).

Concerning the former, the plain area was easily defended, not just by the 8 bastions built in the 17th century, but especially due to its flooding, which hindered the establishment of artillery batteries. For example, in the eighteenth century and the first half of the nineteenth century, 55 different floods were recorded. Flash floods caused the water to reach heights of up to 2 metres in the lower parts of the city (Ripoll et al, 2020). The river that most often broke its banks is the Ter (37 times), followed by the Onyar (33 times), the Galligans (13 times) and finally the Güell (7 times). The rivers that directly caused most damage to the city are the Galligans and the Onyar. These characteristics are very much taken into account by both the military engineers who designed the defences of the city and, above all, by the attacking armies in their approach to laying siege. 
The rocky subsoil of the mountainous area is characterized by being formed of highly compact, resistant calcareous nummulitic sedimentary rocks. In military siege strategies on fortresses located in these kinds of mountainous areas, this geological peculiarity made it enormously difficult for the attacking army to dig trenches and passageways in the subsoil, and greatly hindered the advance of siege troops as it forced them to advance on the surface in full view (Fig. 2).

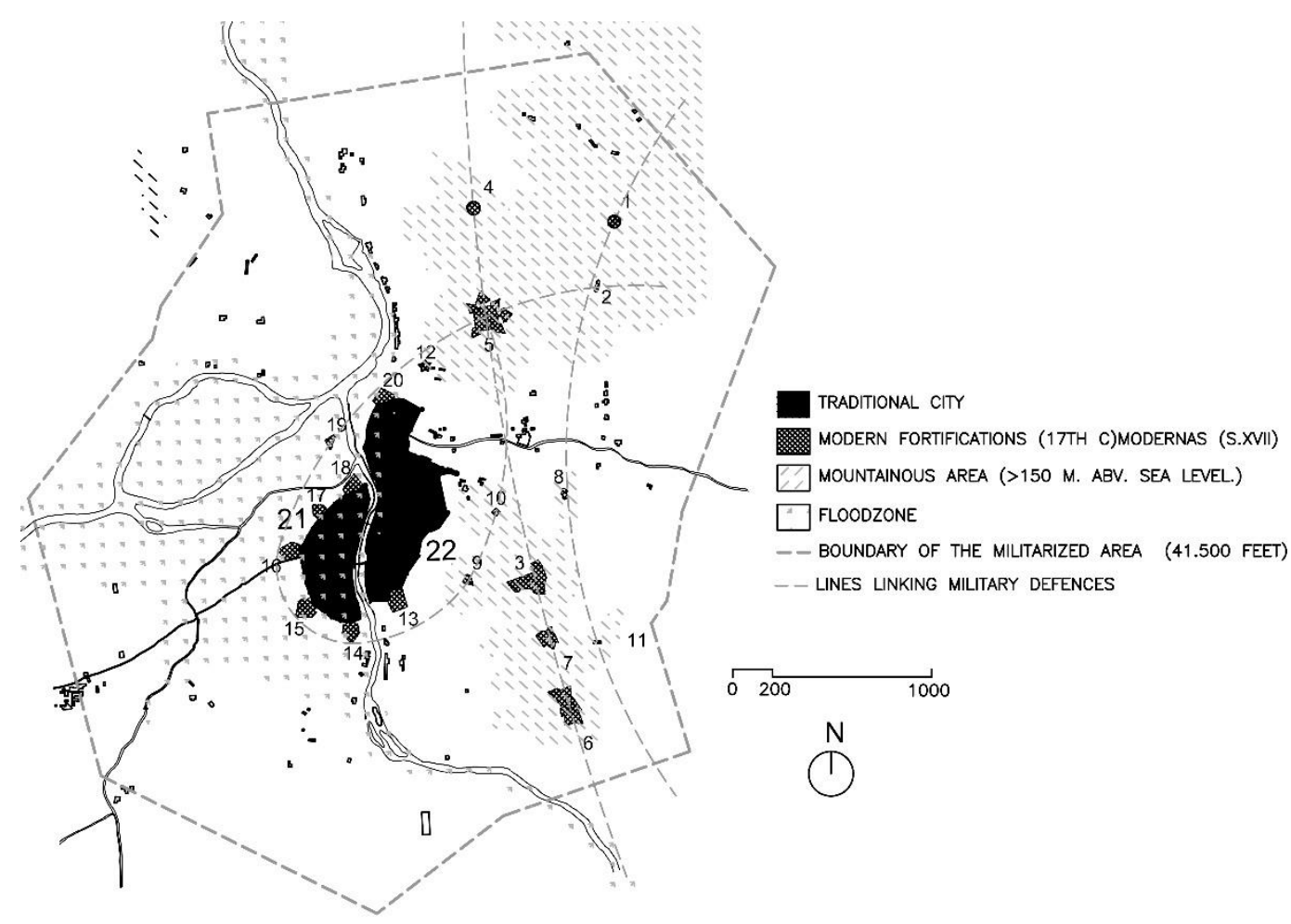

Fig. 2. Fortifications of the city of Girona in the 18th and 19th centuries

(Drawing by R. Ripoll, private archive, 2018).

\section{DEFENCES CONSTRUCTED}

In the seventeenth century, in the mountainous area of Montjuic and Pedreras, 11 fortresses and facilities were built covering an occupied area of 74,855 m2. These fortifications, which are located between 160 and $218 \mathrm{~m}$ above sea level, were perfectly arranged, with an average distance between them of $255 \mathrm{~m}$ (between 170 and $390 \mathrm{~m}$ ), allowing creating a protective line of defence in the east of the city (Table 1).

During the seventeenth century, in the Girona plain, in the west of the city, attached to the ancient city walls, 8 triangular bastions were built. These bastions covered an average surface area of 5,400 $\mathrm{m} 2$ each (between 1,830 and 7,775 $\mathrm{m} 2$ ). For their construction their due arrangement was especially taken into account. They were situated at an average distance of $162 \mathrm{~m}$ apart (between 127 and 186 $\mathrm{m}$ ) and were located in the low areas of the city and therefore at an average height of $68 \mathrm{~m}$ above sea level (between 67 and $93 \mathrm{~m}$ ). 
Features of the fortifications of the city of Girona in the 18th and 19th centuries.

Table 1.

\begin{tabular}{|c|c|c|c|c|c|}
\hline & AREA & SURFACE AREA & ELEVATION & DIST A & DIST B \\
\hline 1 & "SANT NARCIS" TOWER & 3,030 & 218 & $250(2)$ & $650(4)$ \\
\hline 2 & "SANT MIQUEL" REDOUBT & 980 & 205 & $250(1)$ & $430(5)$ \\
\hline 3 & "CONDESTABLE" FORT & 16,800 & 190 & $170(7)$ & $172(9)$ \\
\hline 4 & "SANT LLUIS" TOWER & 3,460 & 186 & $390(5)$ & $650(1)$ \\
\hline 5 & "MONTJUIC" FORT & 23,380 & 185 & $241(12)$ & $390(4)$ \\
\hline 6 & "CAPUTXINS" FORT & 16,155 & 185 & $212(7)$ & $242(11)$ \\
\hline 7 & "REINA ANNA" FORT & 6,725 & 185 & $170(7)$ & $212(6)$ \\
\hline 8 & “DEL CALVARIO" REDOUBT & 1,240 & 170 & $335(3)$ & $319(10)$ \\
\hline 9 & “DE LA CIUDAD” REDOUBT & 1,735 & 165 & $172(3)$ & $303(13)$ \\
\hline 10 & "DEL CAPITOL“ REDOUBT & 900 & 160 & $319(8)$ & $306(3)$ \\
\hline 11 & AMMUNITION DUMP & 450 & 160 & $179(7)$ & $242(6)$ \\
\hline 12 & "SANT JOAN" TOWER & 1,710 & 120 & $180(20)$ & $440(5)$ \\
\hline 13 & "DE LA MERCE" BASTION & 6,635 & 93 & $186(14)$ & $303(9)$ \\
\hline 14 & "SANT FRANCESC" BASTION & 6,150 & 69 & $186(13)$ & $152(15)$ \\
\hline 15 & "SANTA CLARA" BASTION & 7,775 & 68 & $152(14)$ & $206(16)$ \\
\hline 16 & “GOVERNADOR” BASTION & 6,855 & 68 & $174(17)$ & $206(15)$ \\
\hline 17 & "SANTA CRUZ" BASTION & 3,475 & 68 & $127(18)$ & $174(16)$ \\
\hline 18 & "FIGUEROLA" BASTION & 5,445 & 68 & $127(17)$ & $168(19)$ \\
\hline 19 & “RAMENVILLE” LUNETTE & 1,830 & 68 & $168(18)$ & $282(17)$ \\
\hline 20 & "FRANÇA" BASTION & 5,260 & 67 & $180(12)$ & $268(19)$ \\
\hline 21 & "MERCADAL" QUARTER-WEST & 151,130 & 68 & & \\
\hline \multirow[t]{5}{*}{22} & CIUTAT VELLA - OLD TOWN & 273,800 & $67-118$ & & \\
\hline & & & & 208.4 & 305.75 \\
\hline & TOTAL FORTIFICATIONS & 4,010 & $22 \%$ & & \\
\hline & TOTAL CITY & 540,910 & $78 \%$ & & \\
\hline & TOTAL & 544,920 & $100 \%$ & & \\
\hline
\end{tabular}

These defences were organized around an independent primary defence element formed by Montjuic fort, with a surface area of $16,800 \mathrm{~m} 2$ (at $185 \mathrm{~m}$ above sea level). This central defensive role is reflected in its four-pointed star shape and an additional two points forming outposts located in the most vulnerable spans. This fortress created three defensive lines over the general city area.

The first line was formed by a protective arch consisting of 8 bastions (França, Ramenville, Figuerola, Santa Cruz, Gobernador, Santa Clara, Sant Francesc, and Merced) supplemented by 3 secondary forts in the first foothills (tower of San Juan, "Ciudad" redoubt and "Capítulo" redoubt) (Fig. 3). The defensive line protected the west of the city and its north and south flanks.

A second line of protection was the one formed by the straight-line arrangement of the five most important fortifications also organized from the starting point of Montjuic Castle (and completed by the tower of San Luis, Condestable fortress, Queen Anna fort and "dels Caputxins" fort) (Fig. 4). This second set of defences was arranged between 170 and $185 \mathrm{~m}$ above sea level, displaying great geographical homogeneity both in plan and elevation.

Finally, a third, eminently preventive line of protection was formed by three fortifications ("Sant Narcis" tower, "Sant Miquel" redoubt and the "Calvario" redoubt) and a facility (Ammunition Dump). In this description we have circumvented the more secondary defensive elements such as guardhouses, trenches, etc. scattered around the fortifications. 
B
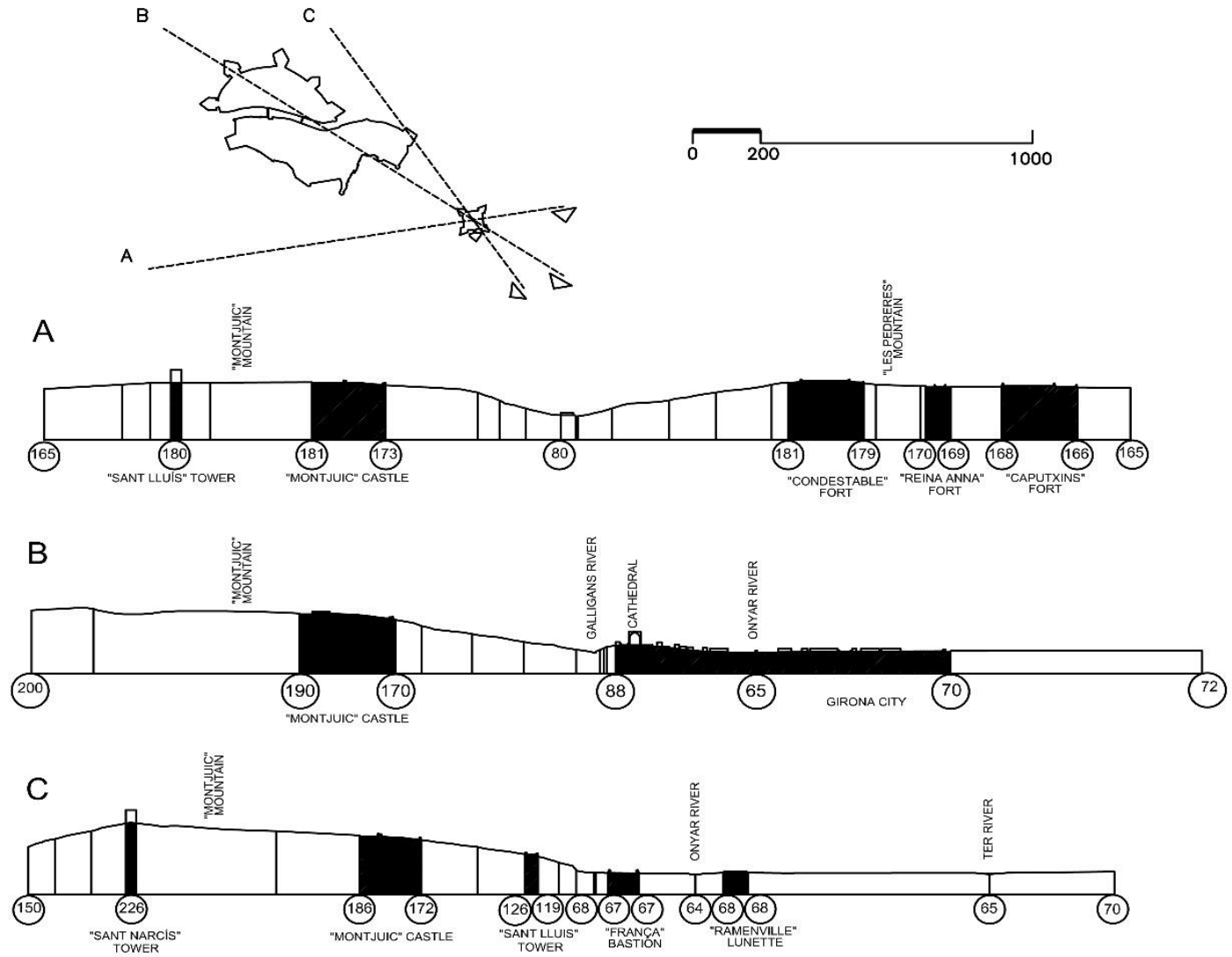

Fig. 3. Sections of the fortifications adapted to the geography of the city of Girona in the 18th and 19th centuries (Drawing by R. Ripoll, private archive, 2018).
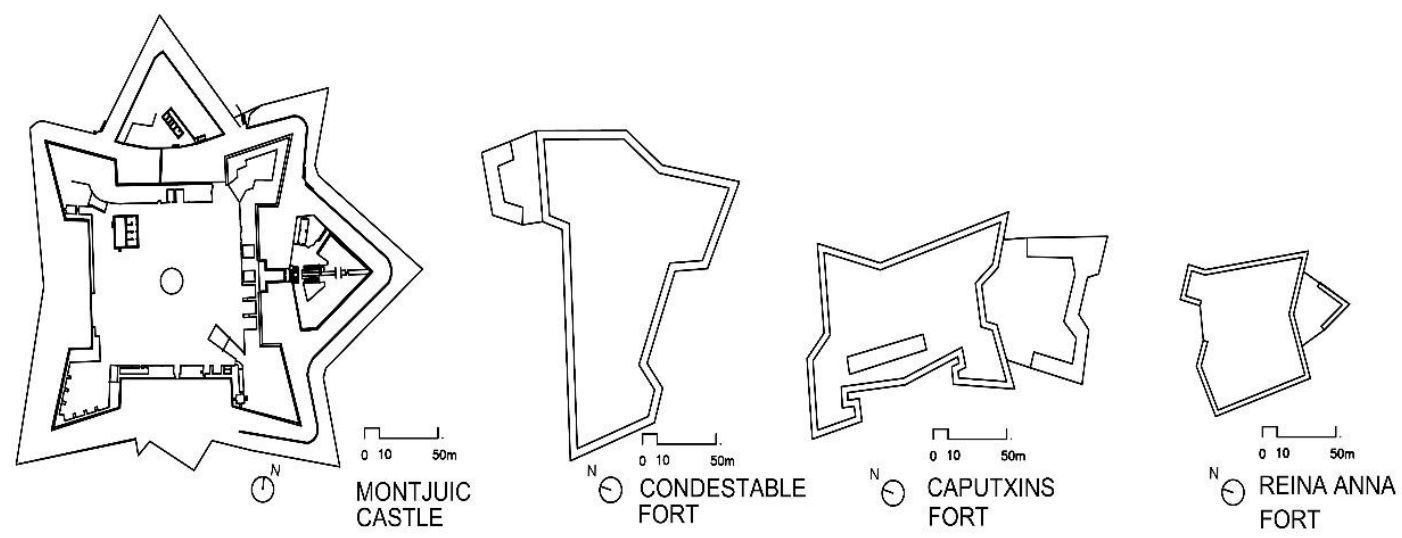

Fig. 4. Form of the isolated fortifications of the city of Girona in the 18th and 19th centuries (Drawing by R. Ripoll, private archive, 2018). 


\section{CONCLUSIONS}

This analysis helps probe more deeply into the adaptation of European defence manuals without breaking away from the fundamental principles that uphold them. After analysing the example of an irregularly shaped fortified European town, it is clear that the excellence of the ratio between form and function does not necessarily require symmetry, regularity and always equal, repetitive models. If it could be demonstrated comprehensively, through the study of a large sample of modern irregular fortifications, it could be stated that the investigations carried out in the twentieth and twenty-first centuries, by modern architecture on the organic form, has its roots in the seventeenth and eighteenth centuries (organic rationalism). In this case the theoretical, methodological and attitudinal similarities would be demonstrated between the best modern military engineers and the most renowned contemporary architects.

\section{REFERENCES}

ACA: Archive of the Crown of Aragón.

AHM: Girona Municipal Historical Archive.

AHG: Girona Historical Archive.

Galindo, J.A. (1996). El conocimiento constructivo de los ingenieros militares del siglo XVIII. Un estudio sobre la formalización del saber técnico a través de los tratados de arquitectura miliar. Barcelona: Universidad Politécnica de Catalunya. (Unpublished doctoral thesis)

Hughes, B.P. (1850). Puissance de feu. L'efficacité des armes sur le champ de bataille. Paris : Lausanne.

Le Prestre de Vauban, Sébastien (2010). The new method of fortification, as practised by Monsieur de Vauban, Together with a new treatise of geometry. Gale ECCO, Print Editions.

Nusit, K., Tantanee, S., Subsomboon, K., Leungvichcharoen, S., Yiemwattana, S. (2019). The desing of flood protection along Nan river, Phitsanulok province, Thailand. Geographia Technica, 14(SI), A special Issue On Sustainable Urban Development, 129-137. DOI: 10.21163/GT_2019.141.26

Odini, S., Tantanee, S., Nusit, K., Buranajarukorn, P. (2020). Factors influencing the uptake of flood mitigation measured in Budalangi, Kenya. Geographia Technica, 15(1), 80-90. DOI: 10.21163/GT_2020.151.07

Ripoll, R. (2001). Girona ciutat de pas. La carretera de dins la ciutat a finals del s.XVIII i principis del segle XIX. Girona. Annals de l'IEG, XLII, 423-434.

Ripoll, R. (2005). L'arquitecte, l'arquitectura i la ciutat. Girona 1760-1835. Barcelona : Publications of Montserrat Abbey.

Ripoll, R. (2009). La volta als Sitges en 43 capitols. Andreu Oller "el primer ciutadà". Girona. Revista de Girona 253, 86-89.

Ripoll, R. (2010). Creixement i servitud militar fora de les muralles de Girona: 1810-1909. Girona. Annals de l'IEG. LI, 403-424.

Ripoll, R., Gomis, J., Turon, C., Chamorro, M.A. (2020). Urban recreational parkc to offset the flooding of rivers: La Devesa of Girona -Catalonia- (19th Century). Geographia Technica, 15(1), 27-34. DOI: 10.21163/GT_2020.151.03

Various authors, 1992, Atlas Girona ciutat XVII-XX. Girona: COAC.

Various authors. 2006. Història de Girona. Girona: Ateneu d'Acció Cultural.

Various authors. 2008. Girona i la Guerra del Francès (1808-1814). Girona: Girona City Council. 